\title{
Earthquakes and tsunami in November 1755 in Morocco: a different reading of contemporaneous documentary sources
}

\author{
P.-L. Blanc \\ Institut de Radioprotection et de Sûreté Nucléaire - BP 17 - 92262 Fontenay-aux-Roses Cedex, France \\ Received: 11 December 2008 - Revised: 7 May 2009 - Accepted: 7 May 2009 - Published: 14 May 2009
}

\begin{abstract}
Tsunami seldom strike the European Atlantic shores. The great Lisbon Earthquake of 1 November 1755 is the main destructive tsunamigenic event recorded. Since the mid-1990's, many simulations of propagation of tsunami waves from variants of the possible seismic source have been conducted. Estimates of run-up in Morocco are seldom included in publications, maybe for want of reliable historical data to control the simulations. This paper revisits some early accounts, transmitted as translations to European Chanceries, Scientific Societies and Newspapers. A critical analysis of the documents leads us to conclude that the Lisbon earthquake was overestimated because of amalgamation with a later Rifian earthquake. Then, the overestimation of the tsunami through worst interpretation of the scant data available appeared only reasonable, while the moderate measurements or interpretations were not given their due attention. In Morocco the amplitude of the tsunami (i.e. height at shoreline minus expected tide level) may not have exceed the measurement given by Godin (1755) for Cadiz, $2.5 \mathrm{~m}$ above the calculated astronomical tide, a crest-to-trough amplitude of $5 \mathrm{~m}$ at most. This age-old overestimation of both the earthquake and tsunami is detrimental to the evaluation of the risk for coastal people and activities.
\end{abstract}

\section{Introduction}

The Andaman-Sumatra earthquake and tsunami, on 26 December 2004 (Boxing Day), has awoken an unprecedented public awareness and anxiety on the risk of a tsunami hitting the coasts of any country: all over the world, coastal settlements or activities, such as fishing or industrial facilities,

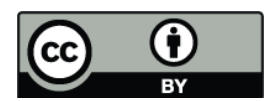

Correspondence to: P.-L. Blanc (paul-louis.blanc@irsn.fr) populated areas or holyday resorts, might prove very sensitive to such events, as well as the lives of the people involved.

The Atlantic shores of Western Europe may not be among the most dangerous places on that account, tsunami being rather infrequent there. The tsunami caused by the Great Lisbon Earthquake, on the morning of 1 November 1755, remains the only destructive event described in some detail by historic documents, though an earlier event known to have occurred in Lisbon on 26 January 1531 (Baptista and Miranda, 2009), was mentioned in journals in 1756, both in France and in England (JHMT, 1756a; Wolsall, 1756, footnote).

The 1755 earthquake was felt all over the Iberian peninsula, but the damages were nowhere quite as extensive as in Lisbon. The tsunami appears to have quickly lost its strength north of Lisbon, (Reid, 1914), either because the waves travelled in a rather oblique direction to the coasts there, or due to the shape and orientation of the accident responsible. It was also destructive on the Portuguese coasts south of Lisbon, it struck rather heavily the bay of Cadiz, and further south, the shores of Morocco. During the two last decades, a number of EU scientific programs have investigated the earthquakes and tsunami in this area (projects DETWS, IAM, GITEC, GITEC-TWO, BIGSETS; Mendes-Victor et al., 2005), attempting to simulate the propagation of tsunami waves from most of the conceivable seismic sources and mechanisms, though this does not make quite clear which tectonic features are the most likely candidates.

A delicate point is the control of the simulations by "real data, deducted from historical reports" as expressed by Mendes-Victor et al. (2005). Recently, the study of a restricted selection of primary documents allowed us to unravel the relationships between some accounts of the tsunami of 1 November 1755 in Cadiz (Blanc, 2008) and to demonstrate that the tsunami was not quite as high as the classical estimates had made it.

Published by Copernicus Publications on behalf of the European Geosciences Union. 


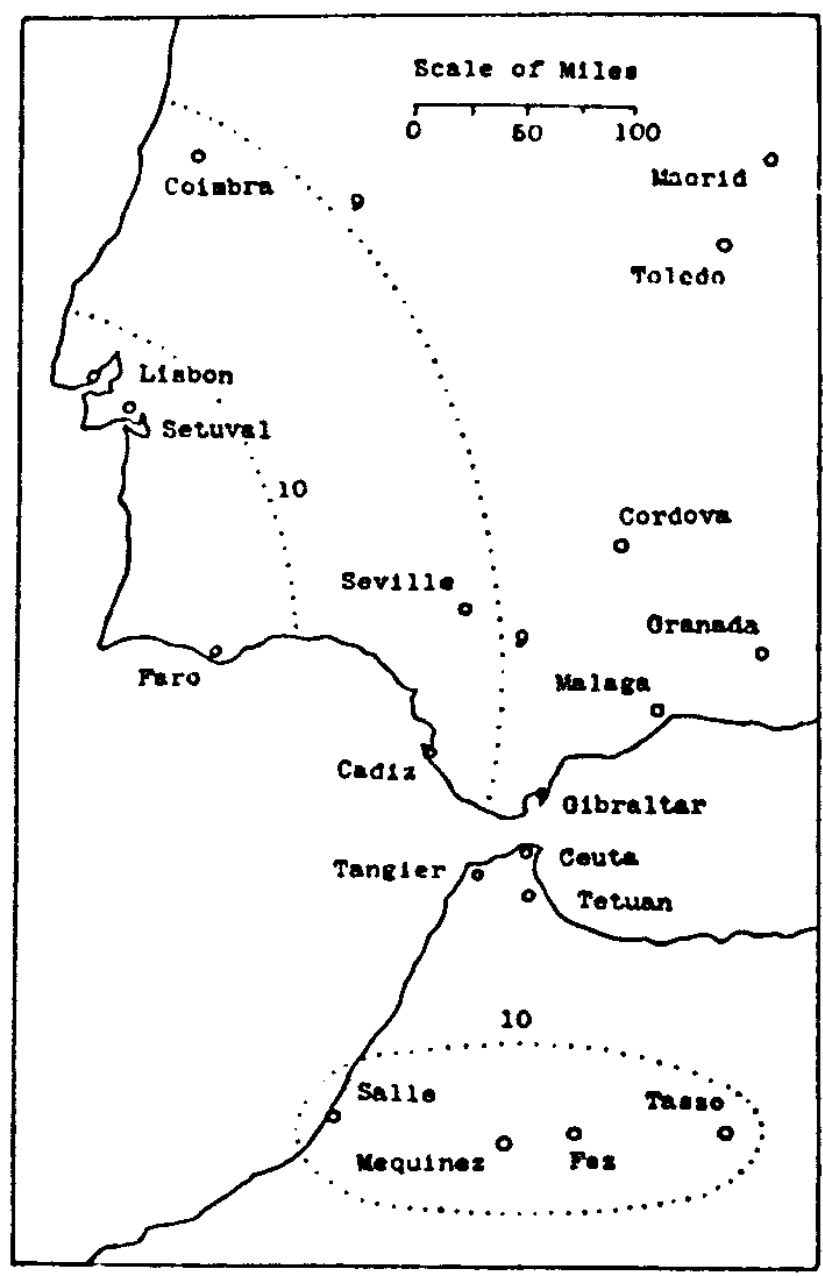

Fig. 1. Isoseismal lines of the Lisbon earthquake, from Davison (1936), showing confusion with the Rifian earthquake of 18 or 27 November 1755.

Estimates of run-up or of height at shoreline on the Moroccan shores are seldom included in the publications reporting on the modelling of tsunami, probably for want of reliable data for comparison to the results of the model runs. Thus, the importance of this tsunami on these coasts has to be revisited: it has to be pointed out to that classical estimates have been that the waves in Tangier reached a height of 14 to $16.5 \mathrm{~m}$ (JHMT, 1756b: fifty feet) and passed over the townwalls. An even wilder estimate is that the wave reached the height of $24.4 \mathrm{~m}$ (Soyris, 1755: seventy-five feet) in Mazagão and other Moroccan harbours further south.

\section{Nature of the documentary sources}

The origin and relationship of the European documents pertaining to the 1 November 1755 earthquake and tsunami, south of the Gibraltar Strait, are quite as devious as those of documents dealing with the European shores.

\subsection{Local descriptions}

Few local descriptions of the events and damages, by reliable direct witnesses, remain or are easily available. The most detailed account which we know of comes from the last harbour detained by Portugal on the Moroccan coast, Mazagão, now El Jadida. The original was a letter by a resident there, printed in the Gazeta de Lisboa when the journal appeared again. Luís-Maria do Couto quoted it extensively in his book entitled "Memorias para historia da praça de Mazagaõ" (date and printer unknown to us), but as far as we know nothing establishes him as the author. We obtained it through a transcription by Pereira de Sousa (1919) of the Gazeta de Lisboa, in Portuguese, and by a French translation of Goulven (1917) of the work of do Couto: despite the different pathways of the two versions, they coincide with each other.

The other local document at our disposal is a letter written on 5 November by Monsieur Soyris, trade agent of a company from Marseilles, based in Safi, but visiting in Marrakech, where he did not hesitate to initiate diplomatic contacts: this explains why his letter can now be found in the Archives Nationales de France (Soyris, 1755; mentioned as Soyvia by Levret, 1991: Soyris was the name of a parish and seigneury in Quercy, now a hamlet of Labastide-Murat, Lot Dept.).

\subsection{Compiled descriptions}

Ancient documents compiling observations on the 1 November earthquake and tsunami in Morocco are more numerous than original local accounts.

Most of the compiled documents proceed to an unfortunate amalgamation between the 1 November Oceanic earthquake, with tsunami, and a Rifian earthquake dated 18-19 November by all European documents or 27-28 by some Moroccan manuscripts (Levret, 1991; Moratti et al., 2003). The isoseismal lines for the 1 November earthquake, as published by Davison (1936), clearly illustrate the age-old state of confusion between these two earthquakes: he had clearly understood that there were two foci involved in the data gathered, but for want of revisiting the original documentary sources (a difficult process, when no automatic reprographic means were in existence), he was not aware that these described two different events, at different dates (Fig. 1).

The compiled reports which we have been able to consult are, by order of recording or publication:

1. Two letters from the French Consul General in Madrid to his authorities, dated 15 and 22 December 1755 (Partyet, 1755a, b); their rather late date (1 1/2 month after the tsunamigenic earthquake, 1 month after the Rifian earthquake) bears testimony to the difficult communications between Morocco and Europe at the time. At least, the 
Rifian earthquake of $18-19$ or $27-28$ November was already mentioned.

To the second of these letters is attached a report, translated by Partyet himself (Partyet, 1755c), entitled "Extract of several letters received by the General of St. Francis from the missionaries of the order who are in Morocco", the first part of which has a subtitle "From Miquenez on 8 November $1755 \ldots$..." followed by an "Extract of a letter from Tetuan on 24 November 1755". The initial document is of clearly acknowledged Hispanic descent: it was a compilation sent by the head of the Order of St. Francis to the Bailiff of Arriaga, minister of Maritime Affairs and of the Colonies of King Ferdinand IV, thus in charge of the relations with Morocco. Some versions of this text were the subject of various editions in Seville, Madrid, Barcelona, and of a Portuguese translation published in Lisbon (all referenced under "Descalços, Franciscanos 1756" in Levret (1991), but this is the name of the order, the Barefoot Franciscans). All of them show a first part supposedly dated 8 November, then a letter of 24 November, purportedly quoting an Express from Fez. It may be a paradox that the French translation, attached to the diplomatic letter of 22 December, might be the oldest copy still in existence: but the Royal Archives of Spain or the archives of the Order of St. Francis may still detain some of the original letters.

2. The exact same title is found in the proceedings of the Royal Academy of Sciences of Paris (Mairan, 1756) for a text read in the session of 7 January 1756. There is no doubt that it is a copy of the same, and the only interest of a careful reading is to correct a few mistakes which found their way therein. The presentation of the two reports making up these documents is ambiguous: the account by the Missionary fathers, written in Meknes, is immediately followed by the Tetuan report, which start with "We have experienced a second earthquake". This wording has made all believe that the first summary dealt only with the 1 November earthquake. The date ( 8 November) globally attributed to the compilation of the Father Guardian of Meknes appears to imply that the damages were caused by the 1 November earthquake, but it may just be the date of the very first letter of the series so summed up. The "Extract of a letter from Tetuan of 24 November 1755", by itself, only lists some results of the Rifian 18-19 November 1755 earthquake. When Levret (1991) compared the effects of the two earthquakes according to both the European and Moroccan sources, a possibility of amalgamation and repeat of data (when towns were deemed twice destroyed) was not considered.

3. In January 1756, the Journal Historique sur les Matières $d u$ Tems dealt with the effects of these earthquakes in Morocco (J. H. M. T., 1756). It does not give the origin of the news which it relays.
4. Another French diplomatic letter, entitled "Extract of a letter of Sale dated 16 November, written by a father of the order of St. Francis, sent to his General in Madrid and translated from Spanish" (Anonyme, 1755), makes use of identical terms, but for a few words, to pages 135-137 of the January 1756 issue of the J. H. M. T. However this letter is not a reliable primary document: despite its stated origin, it precisely does not mention Sale; though dated 16 November, it mentions twice the Rifian earthquake, and it refers to a letter from Tetuan, itself mentioning an express from Fez, just as did Partyet's letter attachment and its transcription by the Royal Academy of Sciences of Paris. Overall, this letter appears to be a summary, under the cover of a different date and a fallacious origin, of the translated appendix of Partyet: but this is the origin of the J. H. M. T. report, even if the journal cancelled the alleged date and origin.

5. Morsy (1976) has published the transcription of a letter kept under the mark C.O. 91/12 in the Public Record Office in London, sent on 1 January 1756 by General Thomas Fowke, Governor of Gibraltar, to his authorities (Fowke, 1756a).

6. A copy was read to the Royal Society of London on 4 March, 1756, and published in the Philosophical Transactions (Fowke, 1756b). The relationship between these two English texts is the same as between the translated attachment to the letter by Partyet and the proceedings of the Royal Academy of Sciences of Paris: the differences result from difficulties in reading exotic place names and in deciphering the manuscript on the occasion of two printings, 220 years apart. Obviously, the Governor of Gibraltar did not witness by himself, in the Moroccan towns which he mentions, the 1 November 1755 earthquake and tsunami, but he does not state his sources. He also refers to the 18-19 November earthquake, peculiar to the region of $\mathrm{Fez}$ and Meknes.

7. As a matching piece of our sample of the French press, we have at our disposal an Account given in the weekly issue of 17 to 24 January 1756 of the Felix Farley's Bristol Journal (F. F. B. J., 1756). This account was reportedly sent on 19 November 1755 by a Gentleman of Gibraltar to a friend in Dublin.

\section{Comparison of the presentation of the documents}

The four French texts begin in the same way, stating that the same earthquake that was felt in Madrid (Partyet, 1755c; Mairan, 1756) or in Spain (Anonyme, 1755, J. H. M. T., 1756b), was also felt in Morocco. One may wonder why the Missionary fathers should mention Madrid or Spain before Morocco: either they already knew of the events in Europe before they wrote to the head of their Order, and that is not 


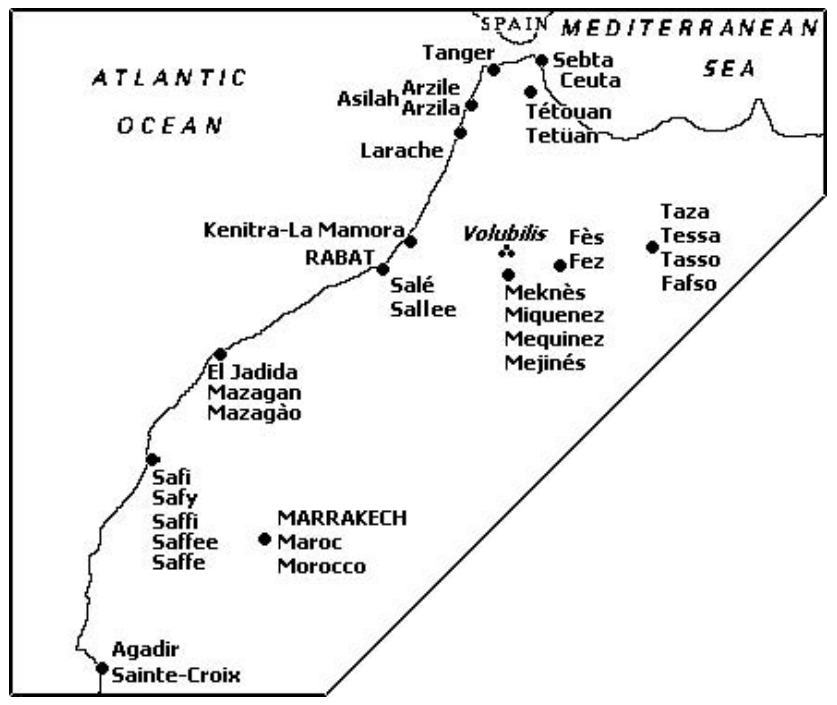

Fig. 2. Location of the towns and harbours referred to in the documents analysed.

to be believed, or the last compiler inserted in his summary some elements of which he knew earlier, and this is the likely explanation.

The phrasing allows some ambiguity in the transcriptions or translations and in the interpretation. The appendix to the letter by Partyet (1755c), read at the Academy (Mairan, 1756), states that the earthquake was felt "in several place in the kingdom of Maroc", the J. H. M. T. (1756) says that it was felt "at Maroc". At the time, Maroc could either refer to the vast territory constituted as a Sultanate independent from the Turkish Empire, which the French still know under that name, or to the town of Maroc, that is to say Marrakech. The same applies for the Spanish Marruecos, hence a strong possibility to ascribe to the immediate vicinity of Marrakech facts or events that simply occurred anywhere else in the country.

None of the texts describes the earthquake itself, only shown through estimates of the number of houses brought down, and of the number of victims buried in the rubble.

All the reports said to derive from a compilation by the Father Guardian of the Royal Convent of Meknes, dated 8 November, begin with a description of damages far inland in Morocco (Fez and Meknes), and even further South (Marrakech). As letters written before the 18 November date should only mention the 1 November earthquake and tsunami, the question arises, whether the oceanic tsunamigenic earthquake caused such damages, or whether this account also describe those resulting from to the Rifian earthquake, which happened later than the alleged date of the document.

The priority of the Guardian of the Meknes Convent was to let his Superior know of the destruction of their church and buildings, as it was important for the General of the Order to pass the information to the Spanish authorities, who were interested in the political role of these missionaries, which was to negotiate the ransom of the Spanish prisoners (slaves) in Morocco. This is the reason why he dealt with the destruction inland first, without much attention to the dates of the events.

The applied outline by the Iberian and French sources considers the Moroccan harbours from the South-West to the North and then to the East. Figure 2 shows the location of the towns and ports mentioned in the text, and variant writing of their name in the sources studied.

The English account by the Governor of Gibraltar (Fowke, $1756 \mathrm{a}, \mathrm{b})$ begins in the East, closest to Gibraltar, undoubtedly important for the British Government, then reviews the harbours from the East to the West and South-West. A description of inland damages is again intercalated: the damages to Meknes and Fez are reported after those to Sale, the normal maritime outlet for these towns, and those in Marrakech, after what pertains to Safi, also the closest harbour to this town.

\section{The damages inland in Morocco, from the letter "from Meknes on 8 November 1755" and the "letter from Tetuan of 24 November 1755"}

The validity of the accepted consistency of composition between the two parts, within each of these compiled documents, does not hold good: despite their supposed date, all the variants of the first text "From Miquenez on 8 November $1755 . . . "$ describe first the destructions in inland Morocco, better attributed to the Rifian earthquake of $18-19$ or $27-28$ November. The second part of each of these reports, ascribed to a letter from Tetuan dated 24 November do not derive from a letter written by Missionaries, and only describe for the second time what happened inland, in Tetuan, Meknes and Fez, at a consequence of the Rifian earthquake.

The question arises whether the written sources make it possible to differentiate, inland in Morocco, between what could be attributed to either of the two earthquakes, of 1 and 18 or 27 November, or if the descriptions only report twice the same damages, news received by the compilers from different sources and not recognized as being the same.

\subsection{Damages ascribed to 1 November}

In the Appendix to Partyet's letter (1755c), the letter supposedly dated 8 November deals with the damages in Meknes, Fez and Marrakech in one single sentence, and rather indefinite at that: "it overturned there several mosques, synagogues and houses, and a great number of moors and jews were killed or injured...". The only further development deals with the engulfing of a douar of at least 11000 people, eight leagues from Maroc, i.e. either in a range of twenty-five kilometres from Marrakech, of almost anywhere in the country, depending on the meaning given to Maroc. One can add 
the piece of information, given in a letter of Partyet (1755a), according to which the Church and Convent of the Franciscan fathers were totally destroyed. As mentioned earlier, this convent was situated in Meknes. The Spanish versions (Navarro y Almijo, 1756; Sanz, 1756) also ascribe the destruction of the Royal Convent of Meknes to the 1 November earthquake.

The diplomatic letter dated 16 November (Anonyme, 1755 ) and the J. H. M. T. (1756) report damages on 1 November in Marrakech only, as well as the same engulfment of a complete tribe.

Fowke's report and its printed version (1756a, b) describe yet again the damages in Fez, Meknes and Marrakech in almost identical terms, but add a particular point for each town: in Meknes, the Franciscan Convent is ruined, but the missionary fathers are safe; near Fez, Jebel Zalagh was split, and released a stream of water as red as blood; 8 leagues from Marrakech, once again a village with 10000 inhabitants is entirely swallowed by the ground, but we obtain the name of the tribe, the Ouled Bou Sebaa. This tribe is now scattered from Morocco (Marrakesh plain or Haouz) to Mauritania through Western Sahara.

The description in the F. F. B. J. (1756) does not mention Meknes, and for Fez and Marrakech it reports exactly the same facts as Fowke, and nothing more.

None of the sources mentioned here describes heavy damage in Tetuan, and no casualties, but the vocabulary can sometimes be a problem. While the English sources report cracks in the walls of various houses, the French use the word murailles, which gives a different size to the damage considered: but it does not appear that the town-walls suffered much.

\subsection{Damages ascribed to 18-19 November}

The damages reported inland in Morocco by the express from Fez cited in the 24 November letter from Tetuan are extensive, and are practically the same in all the studied documents.

According to the Appendix to Partyet's letter (1755c and Mairan, 1756), Meknes would have been completely destroyed: "there remains barely a few houses standing, and even those are heavily damaged". The other documentary sources (Anonyme, 1755; J. H. M. T., 1756; Fowke, 1756a, b; F. F. B. J., 1756) mention the same events in terms which differ but little. A comparison of the number of casualties in the aforesaid town is instructive. According to the translation by Partyet, " 4000 moors died; the great Jewry, in which there were sixteen thousand people has been totally overturned, and those who escaped numbered only eight [thousand?]". In French, this sentence is ambiguous, and we tried to translate the ambiguity in English: one can understand that there has been 15992 Jews killed, besides 4000 Muslims elsewhere in town; but if mille (thousand) is implied at the end of the sentence (as we show), one can understand that in the Jew- ish community 8000 people were killed or disappeared, and 8000 survived. And these two interpretations were immediately adopted: the 16 November letter (Anonyme, 1755) printed in the J. H. M. T. (1756) states that the earthquake "compelled all the inhabitants to withdraw to the country, with the exception of 4000 moors buried under the ruins, and of 8000 Jews, who lived in a separate district, whose number amounted to 16000"; while Fowke (1756a, b), without working out an estimate, states that "in the part of the town called the jews' habitation only eight persons were saved". The F. F. B. J. also declares that "all the people of that sect perish'd, except seven or eight", though reducing the total to the 4000 casualties mentioned by other documents for the Muslim victims only.

This is not a relevant scientific information: these estimates are obviously speculative. The importance of the information is that it demonstrates that these accounts, deemed French or English, are not independent from each other. The wording of Fowke necessarily follows from a formulation similar to that of the Partyet's Appendix, with intermediate Spanish texts such as the Extensa y Completa Relación... of Sevilla (Navarro y Almijo, 1756): "in Meknes, the Jewry consisted of sixteen thousand, and of so many people, it remained only eight [thousand?]" or the Copia de Carta, escrita por el Padre Guardián... of Madrid (Sanz, 1756): "And the Jews of the great Jewry of all those who lived there, (whom they assure to have been 16 thousand people), only eight [thousand?] escaped alive...". The omission of the implied "thousand" word must be attributed back to a previous manuscript, maybe a hurried draft, the common origin of the Spanish and Portuguese printed versions, of the French diplomatic letters, of the proceedings of the Paris Academy and J. H. M. T. and of the English texts of Fowke and F. F. B. J.

The two most reliable documents (Partyet, 1755c; Fowke, 1756a), arrived by the official path and registered by the $\mathrm{Au}-$ thority, one in France, the other in England, mention that Jebel Zerhoun (transcribed as Sargon or Sarjon) was rent into two, and did swallow, according to Partyet, or bury, according to Fowke, the village of Mulay Idris (Ieris, Teris) and another township or tribe. In this case, we have a few accurate data on the places. The town of Mulay Idriss developed around the Mausoleum of the founder of the first Moroccan dynasty, the Idrissid (Idris the 1st Ben Abdullah Ben Al Hassan Ben Ali, great-great-grandson of the Prophet by his daughter Fatima, spouse of Ali, according to the classical lineage), on a hill at the entrance of a valley at the foot of Jebel Zerhoun. This is not far from the ancient Volubilis. Levret (1991) mentioned that the collapse of some of the last Roman buildings still standing was attributed to the 1755 earthquake by Chatelain (1968): as no rebuilding took place, the materiality of the damages remains indisputable in Volubilis... but Mulay Idriss was rebuilt.

In Fez, the reports on the destructions on 18-19 November remains extremely indefinite in all the documents studied, 
but both towns (the old eighth century town and the new fourteenth century town) are said to be ruined, with 3000 dead.

Last, again in these two most reliable documents, the town of Taza (Tessa, Tasso, Fafso) is deemed swallowed, with nothing left.

The destructions reported by the accounts of the 18-19 November earthquake are thus particularly attached to the Northern flank or the Miocene South-Rifian corridor: both the Jebel Zalagh and Jebel Zerhoun are found north of the two great Moroccan metropolis, Fez and Meknes; Moratti et al. (2003) illustrated convincingly some co-seismic movements on the slopes of these mounts. We do not have any knowledge of such observations close to Taza, the structural position of which, at the border between the pre-Rifian ridges and the Moroccan Meseta, still make it very likely that it was struck by the earthquake, though not to the point of disappearance.

The cross-examination of these documents results in a deep inconsistency: each of these texts encompasses two testimonies on what happened inland. There is no possible doubt that the Rifian earthquake of 18-19 November struck heavily Meknes (plus Jebel Zerhoun, Volubilis and Mulay Idriss), Fez (and Jebel Zalagh) and probably Taza. On the other hand, a destruction of Marrakech has been ascribed by all the European documents compiling the observations, to the 1 November earthquake. An earthquake located north of the Horseshoe abyssal plain, close to the Gorringe Bank and Marques de Pombal thrust would then be the cause of extensive damage on the border between the Moroccan Meseta and the Atlas chain.

\subsection{Marrakech: a counter-testimony by M. Soyris}

Fortunately, we have at our disposal a local testimony on the situation in Marrakech on 1 November 1755. A French commercial agent, Soyris, whose travel also had diplomatic, though unofficial, purposes, did write there, in Marrakech, a letter, on 5 November, only four days after the events (Soyris, 1755). He talks at length of his audience with the Governor of Marrakech, Prince or Imperial Highness Sidi Mohamed III Ben Abdullah, son (and successor two years later) of Sultan Mulay Abdullah IV Ben Ismaïl, as well as of his interview, the day before he wrote, thus, on 4 November in the evening, with Prince Mulay Idriss, brother by marriage and counsellor to the Governor. Soyris did not allow himself to be engrossed by the earthquake, which he indeed had felt, as he provided us with accurate pieces of information on the time and duration: "The first of this month at nine hours $39 \mathrm{~min}$ in the morning we had a violent earthquake, which lasted the space of $8 \mathrm{~min}$ ". These details lead us to assume that we have here a direct witness, and who indeed had a watch. He does not mention that his audience with the Governor, which took place on the very same day, was cancelled or disrupted: if the earthquake had been very strong, it would certainly have terminated the interview and dismissed the visitors to safety!
He does mention some damages, but only by hearsay: the wording "some houses collapsed and very few people happened to be buried under the ruins" certainly does not express the shock that an eyewitness would have experienced. Soyris also mentions that the harbours of Southern Morocco sent couriers to the Prince to apprise him of the same earthquake. And he gives us a complementary information, exactly opposite to what could be believed from the published testimonies: "It appears that it has been stronger towards the North than it was towards the South". Levret (1991) mentioned this letter by Soyris, but only took it into account by down-grading the intensity of the 1 November earthquake in Marrakech from VIII to VII.

\subsection{Conclusion on the damages caused inland by the November 1755 earthquakes}

Two other inconsistent conclusions are reached:

1. From the compilation of the Franciscan fathers, allegedly dated 8 November or 16 November, it follows that Marrakech suffered more from the 1 November earthquake than Fez or Meknes. The 24 November letter from Tetuan, cited in every variant of the compilation, does not mention any damage in Marrakech.

2. From the local testimony of Soyris, it follows that the town of Marrakech did not really suffer from the 1 November earthquake: maybe some building in bad condition was shaken, some poor people may have been knocked down by the fall of a cornice or of a balcony, but there can have been only a few isolated victims.

The only way to reconcile these testimonies is to accept that the 1 November earthquake, in fact, destroyed none of these three localities. The damages in Meknes and in Fez, as a result of the oceanic earthquake, must be reduced to very little. The conclusion of Levret (1991) was "we still need to dispel remaining doubts as to the cataclysmic destructions described for the 1 November earthquake in Fez and Meknes by European sources only...". The initial compiler of most European published documents already knew of both the Oceanic and the Rifian earthquake, and had a bad knowledge of Moroccan geography, and ascribed the whole of the accounts at hand to the 1 November event: he mentioned only the date of the first of the letters which he tried to synthesize, and so antedated his text. All the documents used in our study, whichever the version, Spanish, Portuguese, French or even English, but for the added mention of Jebel Zalagh and of the name of the Ouled Bou Sebaa, carry exactly the same set of observations.

It is only later in November, either on the $18-19$, or on the 27-28, that Meknes, Fez and Taza underwent the Rifian Earthquake. 
The question of the date cannot be solved by the analysis of ancient European documents: the first describers of these events certainly had a mind clear enough to ascribe the events to their proper date, but the texts which we read now are at best only the originals of the final record. These documents have been adulterated at each copy, as proven by a word-toword comparison between copies as close as the Appendix to the 22 December letter of Partyet (1755c) and the copy in the proceedings of the Royal Academy of Sciences of Paris (Mairan, 1756). Between the Appendix and the Proceedings, only one copy was intercalated, which was sent from the Ministry of Maritime Affairs to the Academy, and which Mairan read. However, this was enough for the time of the earthquake to shift from 09:45 (9 heures trois quarts, Partyet, 1755 c) to $09: 20$ ( $9 \mathrm{~h} 1 / 3$, Mairan, 1756), introducing a difference of twenty-five minutes. The time of the tsunami, already unreliable in Partyet's Appendix (10:00 a.m., but the tsunami cannot have reached Morocco in one quarter of an hour, as it took 78 min to reach Cadiz: it may have been 11:00 a.m. in the initial Spanish text) gains $5 \mathrm{~h}$ of advance (tsunami at 06:00 a.m., three hours and forty-five minutes before the earthquake! Mairan, 1756) just because Dix heures (cursive) has been changed for 6 heures (arabic numeral) in the course of two successive copies. We can point out to these mistakes, because we have at hand two very close links in the transmission chain, and a knowledge of their relative precedence, but this leaves an open possibility that other mistakes, of which we have no epigraphical proof, may have slipped in during prior copies.

As to the date of the Rifian earthquake, all European documents refer to 18-19 November, while the Arabic documentary sources are said to record a date equivalent to $27-28$ November (Levret, 1991), but the possibility of similar adulterations of the dates at some time of their recording is just the same as for the European documents: nothing can be demonstrated.

Overall, of all the inland damages ascribed to the 1 November earthquake in the compilation by the General of the Order of St. Francis, the only one having a material existence, however difficult to assess, is the ruination of the Royal Convent of Meknes; it can only be attributed to the Rifian earthquake, and it turns to be one of the elements demonstrating that the compilation of the texts making up the "Extract of several letters received by the General of St. Francis from the missionaries of the order who are in Morocco", is in fact more recent that this Rifian earthquake.

\section{The 1 November tsunami on the Moroccan coasts ac- cording to the letter "from Meknes on 8 November 1755"}

We must now review the damages caused by the 1 November tsunami in Moroccan harbours, according to the texts deriving from the Franciscan accounts.

\subsection{Safi and Agadir}

The damages mentioned in Safi (Safy, Saphi, Safee) and Agadir (Ste Croix) range from "several houses destroyed" to "many houses and buildings overturned", but remain extremely blurred. As a matter of fact, the French documents (Partyet, 1755c; Mairan, 1756; Anonyme, 1755; J. H. M. T., 1756) do not even grant a separate paragraph to each of the two harbours! The report by Fowke (1756a, b) does not consider Ste Croix. The total lack of specificity does not make these damages very compelling. Nor could they be clearly ascribed either to the earthquake or to the tsunami, except for the presence of floated debris and dead fishes in the streets or the destruction of boats: nothing specific either.

\subsection{Sale (Rabat)}

Further to the North, in Sale (and Rabat), the damages caused by the Earthquake are not better described, as the wording is "the same havoc took place in Sale; the sea inundated all the streets, houses, stores..." (Partyet, 1755c). At variance, the mention of the tsunami wrecking the ferries while they crossed the estuary of the river Bou Regreg (Fowke, 1756a), and the drowning of 200 victims, are particularly plausible. The number of boats does not appear quite fixed, two according to the English sources, three according to the French and Spanish. For the F. F. B. J., the victims were fishermen, but the approximate number of 200 indeed implies that these boats were ferries. Without underestimating the misfortune of these people, overturning ferries on an estuary does not require an extreme event, such boats being rather vulnerable. A single wave of the tidal bore type might suffice to the result described in our documents, and these ferries can only have been overturned by the first wave: certainly, no boat took to crossing the estuary later that day.

On the other hand, the statement that "the ground has swallowed a large caravan of camels and mules" most probably results from the mistake of a copyist, but it is already found in the Spanish versions of the letter. The English sources, though they do not appear independent from the letters of the Franciscan Fathers, ascribe the disappearance of this caravan to the tsunami: "a large number of camels, that were just going for Morocco, were carried away by the waters" (Fowke, $1756 a, b)$. This can easily be explained if we assume that this caravan, which was just leaving Sale, followed the strand itself, on easy ground for the camels' feet. The unhappy beasts of burden could not escape with the load tied on their back and flanks: neither in this case is it necessary to ascribe an extreme violence to the event.

\subsection{Asilah}

In Asilah, the damages, described as important, are contradictory. According to the French sources (Partyet, 1755c) the town suffered much, both of the earthquake and of the 
tsunami, and there was an infinite number of casualties: "The sea came in as far as mid-town, a thing which, added to the earthquake, has ruined the greater part of the buildings, and those that remain are rather shaken: several bâtimens were submerged...". This is one of the cases in which the meaning of the word Bâtiment may remain doubtful: architectural building or vessel? To the opposite, for the official English report (Fowke, 1756a, b), casualties happened only out of the town walls, and it is clearly stated that the waters only came into town through the Sea Gate: "The damage was not so great at the coming up of the sea though Moors who were out of the town wall were drowned, and the waters came in through one of the city gates very far...".

The damages caused to the vessels which were in the harbour (little more than a re-entrant angle of the town-walls at the time) were important, and more spectacular than the damages to the town: "several vessels were submerged and a large English Pink was carried to the middle of the town..." (Partyet, 1755c); "The water came up with such an impetuosity that it lifted up a vessel in the bay which (at the water's falling down to its centre again) fell down with such a force upon the land, that it was broke to pieces; and a boat was found at the distance of two musket-shots within land from the sea" (Fowke, 1756a, b).

These testimonies are not easily interpreted. That several vessels were submerged is easily explained: the limiting factor, in the case of a tsunami, is the number of ships available to undergo the shock and destruction. At variance, on the topic of the specific cases described, it is difficult to ascertain that we have more than the fate of a single vessel. Considering that these accounts are only summaries of the prior synthesis of an unknown number of primary letters, it is quite possible that the nature of the ship, a Pink, the fact that it was carried into the town at a rather indefinite distance, and that as a result it was broken to pieces, may well describe a single particular event. Can we precise the description?

1. The type of boat: the Pink was a merchant ship with lateen sails. Its hull could be rounded or flat-bottom. It generally had three masts, with lateen yards, and was mainly used in the Mediterranean. The burden could be up to two or three hundred tons. It had a very high stern. At the turn of the nineteenth century this type of vessel could reach $6.5 \mathrm{~m}$ in width and $24 \mathrm{~m}$ in length, with a rear draught of $3 \mathrm{~m}$, but it is likely that the units of the mid-eighteenth were lighter, be it to keep the speed and manoeuvring capacity needed to escape the privateer war between Muslims and Christians.

2. The distance: two musket shots, twice the range of the infantry gun of the time. It must be the practical range, at which the shooter expects to see the effect of his single shot on what he aimed at. The French ordnance gun typical of the time was a smooth barrel weapon, 17 to $17.5 \mathrm{~mm}$ bore, firing lead balls of $16.5 \mathrm{~mm}$ diameter. The practical range, single shot, a distance at which the shot brings down the man who is aimed at, rather than his neighbour, was about $60 \mathrm{~m}$. In volley fire, the efficient range was double. Thus this ship may have been found $120 \mathrm{~m}$ in town.

3. The way by which it got there is difficult to elucidate. Some exegesis of these texts have deduced that the tsunami wave did overtake the ramparts to the point of carrying this boat above them, but this is in contradiction with the report of Fowke, who asserts that "the waters came in through one of the city gates". Then, we have to consider another possibility, which would be that the ship was pushed under the arch of the Sea Gate by the entering flood, making it run less than ten times its own length (of a ship $16 \mathrm{~m}$ long?) in town, before it sank on the spot, as a result of the damage sustained (tearing of its masts), without being actually engulfed, for want of water depth, as the flood was spreading before flowing out again. Another, rather pedestrian possibility is that there can have been a breach in the town walls, and the tsunami pushed the ship through, but no such breach is mentioned by any contemporary text.

\subsection{Tangier}

Tangier is mentioned (with the harbours of Larache and La Mamora) in the Appendix by Partyet (1755c), but in terms so indefinite that they cannot be considered as a description of actually observed damages: "several buildings were ruined, and many people drowned...".

The Journal Historique (J. H. M. T., 1756) is the only one of the French documents which we consulted, to mention that in Tangier, "the sea, on the shore came up of fifty feet, and the waters in this surge lost almost all their bitterness and saltiness"; these assertions are not found in the diplomatic letters. The second proposition is preposterous: sea-water cannot be spontaneously desalinated, even during a tsunami, and who would have the idea to taste it under such circumstances? As for those who tasted it against their will, this is probably not what they had to tell, if they had the luck to survive. This statement is a good measure of the reliability of this testimony, and as a result it is not very plausible either that the water reached such a height (from 14 to $16.25 \mathrm{~m}$, whether the foot considered is the Spanish Pié or the French Pied de Roy). This could be a crest to trough height in the case of a strong tsunami, certainly not the water height at shoreline.

The English sources are more explicit about the earthquake itself, and describe clearly enough a notable accident: "a large promontory of an old building near the city gate, after three shocks, fell down to the ground, by which five shops were demolished..." (Fowke, 1756a, b); "a great pile of ancient building near the gate of the town, after two or three movements, tumbled down, and killed several people..." (F. F. B. J., 1756). Nevertheless, it is not so easy to know what the building was, and where the accident took place. The present Kasbah of Tangier has more than one 
single door! Besides, the English describers obviously did not know what the collapsed building was, the word promontory being a term of geomorphology much more than of architecture; as for the term great pile, it rather describes the final state. The shops demolished may just have been the fairground stall type.

The descriptions of the tsunami in the English texts are contradictory. According to Fowke (1756a, b), "the sea came up to the very walls, a thing never seen before": but the reading by the Bristol Journal (F. F. B. J., 1756) is quite different: "the water flowed over the town walls (a thing never seen before)". The difference is significant: that the sea came up to the wall only means that it reached the foot of it! It is not credible that the tsunami wave can have overtaken the rampart of Tangier, the Kasbah of which is not a low town as can be Cadiz, in Spain, or Asilah. Nevertheless, what follows in the testimony, including the wording of the unique character of the event, "a thing never seen before", shows that the data, of which Fowke and the correspondents of the F. F. B. J. benefited, were the same, if indeed the "Gentleman at Gibraltar" and his "Friend in Dublin" were not just a more or less licit copy of the report of Fowke.

The facts described are almost the same, and the wording quite close: "the sea went down directly with the same rapidity as it came up, as far as the place where the large vessels anchor in the bay, leaving upon the mole a great quantity of sand and fish. These commotions of the sea were repeated 18 times, and continued till six in the evening, though not with such violence as at the first time as to the shore side, the waters came up half a mile inland" (Fowke, 1756a, b) and "the water leaving behind it, at its return, a vast quantity of fish and sand, and in like manner it continued to rise and fall about eighteen times in the space of eight hours" (F. F. B. J., 1756). But the testimony of Fowke implies that the fishes abandoned by the drawdown of the water were deposited on the breakwater, and quite out of the town precincts: if fishes had been deposited everywhere in town, why should one mention that some were left on the mole of the harbour? This is in accordance with the fact that the town walls were not overtaken, even closest to the sea. There is thus a discrepancy with the idea that the wave could have overrun the ground half a league inland (1/2 British league is equivalent to 1.5 statute mile or $2.4 \mathrm{~km}$ ), or it would have to be on the large beach, towards the east of the bay of Tangier, and quite far from the old Kasbah, the only urbanized area in the eighteenth century. Such discrepancies are not unexpected in a description coming from the compilation of uncoordinated accounts. The idea that all the fountains in Tangier ran dry also reappears, which seems to be a repeat of indications more specifically attached to the Rifian earthquake.

\subsection{A local account from the Portuguese stronghold of Mazagão (EI Jadida)}

The letter from Mazagão, now El Jadida, initially published in the Gazeta de Lisboa provides us with some pieces of information which are not found in the Spanish, French or English texts, but tend to the same meaning. The earthquake occurred at $91 / 2 \mathrm{~h}$, and its duration was estimated to $1 / 4$ of an hour. It does not report any destruction of building by the earthquake, but only the opening of holes in various places (... abrindo bocas em varios sitios...), most likely cracks rather than holes. Of course, it also dwells upon the fright of the people.

The text dealing with the tsunami is the most detailed that we found on the event in Morocco, thus warranting an extensive quotation (as quoted by Pereira de Sousa, 1919 and translated to French by Goulven, 1917):

"the sea, with an horrible motion, jumping over the rocks and bashing the gates in, flowed into the precincts of the place, where, when it receded, it left many fishes. Everybody was afraid and took refuge on top of the walls; and where the Governor met only his first-born son, Fernando Pereira Leyte de Sousa, who was on watch at the gate, where he remained with water up to the waist, abandoned by all his companions.

The sea raged until $2 \mathrm{~h}$ in the afternoon, carrying away in its undertow bales, laying waste almost to the naked rock the earth where broad beans and barley had been sown, and the meadows where horses grazed: it has ruined the outer fortifications, the fences and the fish-traps. Of the ships and boats of his Majesty, some were lost and others destroyed".

From this testimony, it follows that the tsunami broke on the rocky tidal platform, levelled on the shore by the astronomical tides and wind waves. The sea came into the stronghold after breaking open the doors (after Goulven; implies "as portas" in Portuguese), rather than the harbours ("os portos" in Pereira de Sousa), as Mazagão did not have any outer port at the time, just a smaller cove notched to the east of the rampart, and a single Sea Gate, opening on that cove. The plural may show that there were two successive gates under the rampart, or just that there were two leaves to the gate. The walls of the Portuguese Place were not overflown by the wave: to the opposite, the people had taken refuge on the parapet walk, and the Governor was walking around, exhorting the people to fortitude.

A tentative estimate of the height of the tsunami may be derived from the circumstances of the Governor's son, the only sentry who did not abandon his post: the water reached up to his waist, i.e. about $1 \mathrm{~m}$ height, if we admit him to have been 1.6 to $1.7 \mathrm{~m}$ tall. He was probably soaked so by the first wave, as we can doubt that he waited for each of the following surges. Without abandoning his watch, he must have had a possibility to climb for safety on the rampart at each rise. 


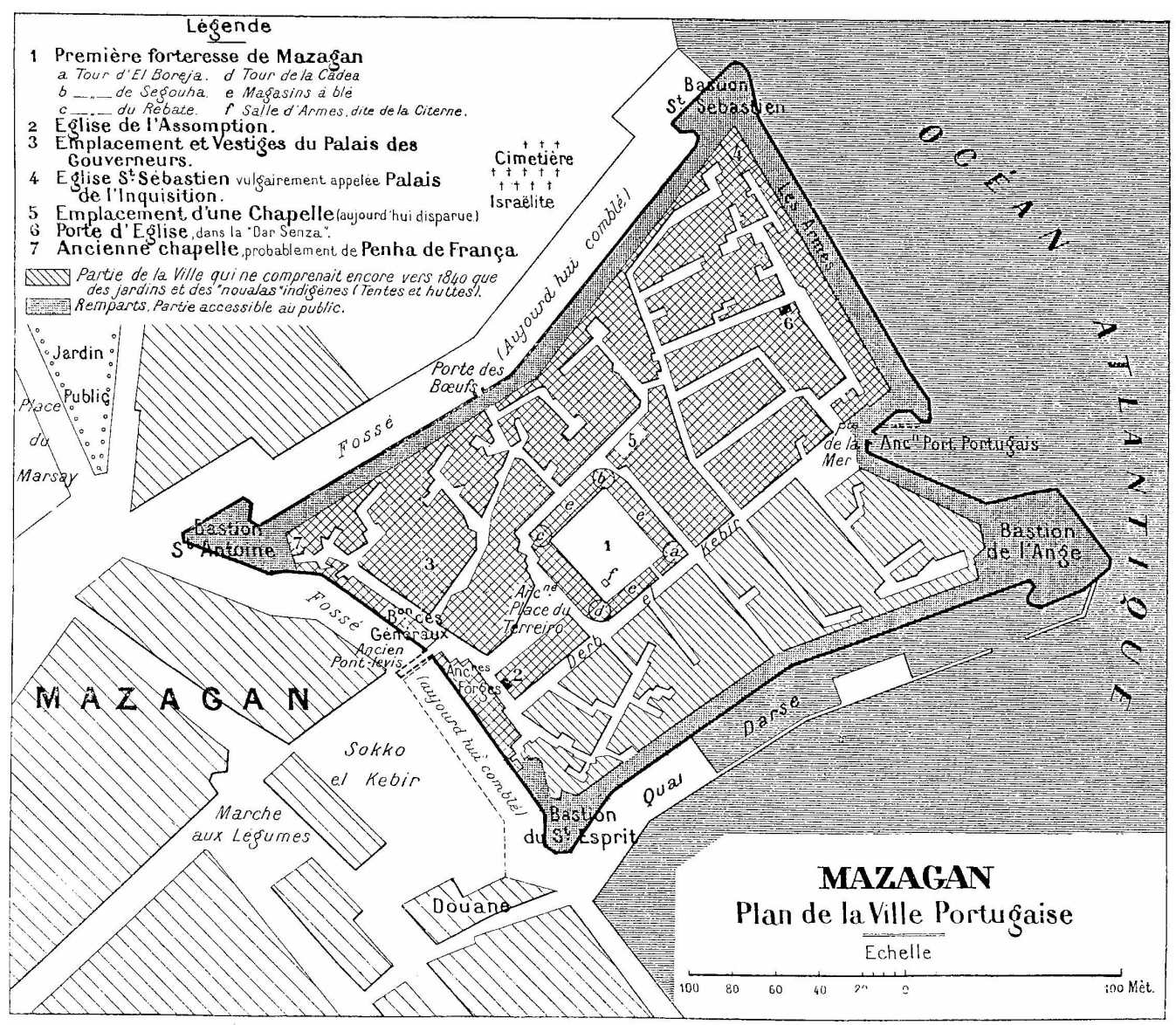

Plan Iressú par H. Gonlven

Fig. 3. Map of the Portuguese fortress of Mazagão, in El Jadida (from Goulven, 1917).

Can we determine which gate he was on watch at? There were only two gates at Mazagão, a Sea Gate to the East, and a Land Gate or Gate of the Redoubt of the Generals to the south-west: a third one, called the Oxen Gate, had been walled up 150 years earlier or so (Fig. 3).

The Governor's son cannot have been on watch at the Sea Gate: this is the place where three people, who were drowned, and a fourth one, barely escaping (the Alcaidemór of the town, and main civil authority?), had been carried away by the first tsunami wave, and brought back miraculously.

Furthermore, we are informed that the successive waves did wear away the ground around the fortified place: all the work done on the ground, cultivation (barley, broad beans, meadows), fences, also set into the ground, as well as the outer defences, which were only trenches and earthen embankments, meant to prevent cavalry raids on the cattle and horses turned out to grass, were carried away when the soil was eroded to the bare rock. Thus, the tsunami waves did circle the fortress, with additional help from the moats, which contained water at the time. The inundation reached the Land Gate.
Thus, the son of the Governor can only have been on guard at the Land Gate, and the circuit of the water around the city explains that the flow weakened to the point of not carrying him away. The estimate of the inundation there is $1 \mathrm{~m}$ above ground at the Gate of the Redoubt of the Generals. But this estimate may not accurately refer to the present state: the Redoubt of the Generals, mined by the Portuguese when they had to evacuate when the Moroccan troops recaptured Mazagão in 1769, does no longer exist as such, and we cannot evaluate the difference in the level of the roadway when the wall was rebuilt. It was probably considered enough to level the ruins before rebuilding the rampart, the present Land Gate may be or not at a different level than the former Gate of the Redoubt of the Generals.

The end of the letter of Soyris (1755) reports quite a different estimate of the tsunami in Southern Morocco, including Mazagão: "they write from the maritime towns that the sea increased three times, of seventy five feet, so much that the Portuguese garrison in Mazagão had been compelled to abandon the City, and to put its freedom at risk by withdrawing more than one league away to the Mountain. Thank God nothing worse happened than fear". There is a contradiction 
with what he stated earlier in the same letter, "it appears that it has been stronger towards the North than it was towards the South". Obviously, Soyris only mentions of Mazagão by hearsay, and there may have been a problem of translation and conversion of Moroccan units to European. But formulated that way, in French, in Soyris' letter, this testimony must be discarded as fabrication: if a wave of 75 pieds of amplitude $(24.36 \mathrm{~m})$ had struck Mazagão, repeated several times at that, Sultan Sidi Mohamed III Ben Abdullah would not have had to recapture this portion of the Moroccan coasts from the Portuguese in 1769, because there would have been no survivor there as early as 1755 . Neither could have taken place any evacuation of the town to the country inland, as the period of the waves would not have allowed anyone to walk any distance away through the devastated surroundings.

\subsection{Conclusion on the tsunami in Morocco}

The critical analysis of documents, closest to primary sources, having reached France and England, allows us to conclude that nowhere in Morocco the amplitude of the tsunami, defined as the difference between the expected level of the tide and the water height at shoreline, can have exceeded the measure given by Louis Godin (1755) for Cadiz, i.e. $2.5 \mathrm{~m}$ above the calculated astronomical tide (Blanc, 2008) or a crest-to-trough double amplitude of $5 \mathrm{~m}$ at most.

Abe (1979) reached a similar estimate: "excluding the anomalously large heights $(15$ and $18 \mathrm{~m})$ from the average, we obtain the average run-up height of $2.8 \mathrm{~m}$ from the data at Tagus River, Oporto, Cadiz, Gibraltar, Ceuta, and Madeira...". To calculate an average value on local observations of a phenomenon, of which we know that it may depend on the location, while excluding from the calculation the high values, may not be statistically correct, but the fact remains: the two strongest wave heights mentioned, concerning Cadiz and Tangier, were actually more than five-fold higher than the mean of other observations.

A wave amplitude of $2.5 \mathrm{~m}$ is enough to explain the events described in any detail:

- in Tangier, the presence of fish, abandoned by the waves on the mole of the harbour, and not within town, as well as the spread of the run-up to the rampart, i.e., at their foot;

- in Asilah, people drowned outside of the town-walls, the coming in of water to mid-town, and the likely forcing of a Pink under the arch of the Sea Gate, and its breaking to pieces;

- in Sale, the overturning of the ferries crossing the estuary of the river Bou Regreg, and the engulfment of a Caravan, beginning its travel to Marrakech on a coastal track;

- in Mazagão, the fact that at the Sea Gate three people were engulfed and drowned, a fourth one barely escap- ing, while at the Land Gate a sentry was able to remain at its post, the skirting around of the ramparts of the fortress by the waters, and finally the fact that out of the precinct the soil and crops, the earthen works, palisades and fences had been fully dismantled.

It is easy to draw a parallel between the events in Mazagão, totally encircled and surrounded by the waters, and where the outer defences were swept away, and in Cadiz, naturally surrounded by the Atlantic Ocean and the Puntales Basin, but where the causeway, on the tombolo leading to the isle of León, had been dismantled; or between the fate of the travellers going to or leaving Cadiz, carried away from the same causeway and drowned, and the fate of the Caravan leaving Sale on a coastal track, and engulfed by the tsunami. There are no scale differences between these events, and this confirms our conclusion, that the tsunami may not have been stronger in Morocco than in Cadiz: to the south it must have been weaker: the causeway, between Cadiz and the isle of León, was stronger than the outer defences of Mazagão, which were only trenches and earthen banks meant to prevent the foray of Moorish cavalry on domestic animals and horses.

The other facts and damages mentioned, though we cannot doubt them (but a doubt can bear on their extent), are not specific enough to feed the analysis. The collapse of houses can have been caused by the earthquake, or by the tsunami, especially so in the case of out-of-walls suburbs, built of sundried bricks, but we have no particulars. The destruction of an unknown number of ships cannot be a conclusive feature.

Even the best witnesses did let themselves overindulge in sensationalism, when they have attempted to extend their words beyond what they had actually seen by themselves, the best example being the contrast between the very moderate testimony of Soyris on what happened on 1 November in Marrakech, and the apocalyptical wave which, according to the same letter, would have hit Mazagão. That peculiar part of Soyris' report can not be believed: maybe it was only added by a copyist, and the local account published in the Gazeta de Lisboa and in do Couto's book, translated into French by Goulven (1917), and extensively cited in Portuguese by Pereira de Sousa (1919), happily makes up for it. Of course, the people who were trying to write syntheses of the events, but had not seen anything by themselves, did not avoid the trap of sensationalism any better than true, but by material obligation only local, witnesses.

\section{General conclusions}

\subsection{Status of eighteenth century documents}

Very few European primary documents (or reproduction or re-issue) remain, written by true witnesses, on the events in Morocco of November 1755. Among the documents used in this study, the only ones to comply with this definition 
are the semi-diplomatic letter of Soyris (1755), only when dealing with Marrakech itself, and the letter by a resident of Mazagão, first published in the Gazeta de Lisboa (Pereira de Sousa, 1919; Goulven, 1917).

The other accounts dealing with Morocco share a common set of information, coming from letters written by missionary fathers of the Order of St. Francis (Barefoot Franciscans) in Morocco. Unfortunately the local reports did not reach us as such, but only as extracts from a synthesis done by the General of the Order, transmitted afterwards as copies or translations to the European Chanceries, Scientific Societies and Newspapers. The reliability and accuracy of the testimonies has suffered very much in the process. Fowke's report may have benefited from supplementary pieces of information from British Ships on the harbours closest to the Strait of Gibraltar: Tangier, Asilah.

\subsection{The events described}

Within inland Morocco, the damages attributed to this earthquake actually result from the Rifian earthquake which happened two and a half weeks later (18-19 November), to which Levret (1991) has drawn attention, and re-documented by Moratti et al. (2003). If extensive destructions took place in Fez and Meknes, it cannot have been caused by a marine tsunamigenic earthquake.

Furthermore, the local testimony of Soyris shows that Marrakech was not heavily struck by this tsunamigenic earthquake: it has been felt, probably without serious damage, and it is likely that it has been so everywhere in Morocco. Neither is Marrakech cited among the towns where the Rifian earthquake has been destructive.

On the coasts, the least indefinite ruination reported is that of an old building close to one of the town gates of Tangier... but which one? The description suggests that the building was high and rather decrepit, the probable truth that such a building may have collapsed is only increased by the fact that Tangier is the Moroccan harbour closest to the possible epicentres. In all other harbours the damages caused by the earthquake itself do not appear to have been more than sporadic.

The tsunami attached to the 1 November earthquake has been observed in all the Moroccan harbours, but it is not possible to appraise the extent of the damages which it can have inflicted on the structures: in the reports and publications deriving from the letters of the barefoot Franciscans, the wording of these damages are as indefinite as absolutely catastrophic. Yet, all these town were encircled with ramparts: still, damages to the ramparts, not even partial damages, are not mentioned anywhere, at variance with what happened in Cadiz, where several tens of metres of the Parapet of the town-walls were torn away from the wall, though the water came into the town mainly through the Caleta Gate and destroyed some houses in the area of la Viña.
As to the height of the tsunami at shoreline, the idea that it could have been of fifty feet (14 to $16 \mathrm{~m}$ ) at Tangier and that it could have flowed over the ramparts (J. H. M. T., 1756b; F. F. B. J., 1756) must be abandoned, just as had to be abandoned the idea of a sixty feet $(19.5 \mathrm{~m})$ high wave in Cadiz (Bewick, 1756; Ulloa, 1756; Blanc, 2008). In the same way, the idea that it could have been of seventy-five feet $(24.5 \mathrm{~m})$ in Mazagão and other harbours in Southern Morocco (Soyris, 1755) must be discarded: either it is a complete fabrication, or there must have been a deep misunderstanding in translating or converting Moroccan units to European units, and an estimate of seventy-five inches (1.9 to $2.3 \mathrm{~m}$ ) might be closer to the truth.

The proofs of an extreme violence of the 1 November 1755 earthquake and tsunami, in Morocco, are extremely tenuous, and do not resist the analysis. The 1 November earthquake has been overestimated because of the amalgamation of the damages caused by both this earthquake and the Rifian earthquake, two and a half weeks later, as well as because of the widespread reports of tsunami and water agitation in Europe, in the West Indies and mistakenly in North America. Then, the over-estimation of the 1 November tsunami and the systematic worst interpretation of the scant data available ("up to the very walls" interpreted as "over the town walls") only appeared reasonable, while the moderate measurements or estimates were not given their due attention.

\subsection{Human consequences}

Martínez Sólares and López Arroyo (2004) ascribe a total of 15 to 20000 people killed, to this tsunamigenic earthquake, of which about 10 to 12000 in Portugal: in Lisbon, most of the victims lost their life to the fire, and only about 1000 deaths were caused by the tsunami (Baptista et al., 1998a). In Spain, 61 persons are known to have been directly killed by the earthquake, and 1234 by the tsunami (Martínez Sólares, 2001 fide Blanco Moyano, 2005). The length of the Moroccan Atlantic coast is about three times that of the SouthWest Spanish Atlantic coasts, the number of Moroccan victims may have been about one-and-a-half to double the Spanish one, taking into account a lower density of populated areas. The damages caused by the earthquake alone may have been less important than in Spain, but the tsunami hit more harbours, though smaller than Cadiz or Seville, as they had no transatlantic colonial trade role. The loss of lives to the tsunami itself might be of the order of 5000 people overall for the three countries, Portugal, Spain (1250 each?) and Morocco. That most coastal town were enclosed in ramparts acted as a mitigation process, even if the doors were everywhere open at the time of occurrence, or were beaten in.

However speculative and imprecise, the number of casualties was extremely moderate by comparison to the earthquake and tsunami of Boxing Day, 2004 in Sumatra, though it has been impossible there to separate the victims of the earthquake from those of the tsunami, but the point is to 
relate them to a believable wave amplitude. Can we ascribe an extremely moderate number of victims to a tsunami wave with an amplitude or run-up of the order of 15 to $25 \mathrm{~m}$ ? This is in the range of the measurements taken on the western coasts of Sumatra after the 26 December 2004 earthquake and tsunami, where and when about a quarter-million people died: not a moderate number.

This is not a matter of historical negationism: there was indeed, on 1 November 1755, a tsunamigenic earthquake in the Ibero-Moroccan Gulf, from the western shores of Iberia to the western shore of Morocco. Both the earthquake and tsunami had harmful consequences for the local population, even if the written record is somewhat imprecise in numerous places. We cannot be surprised any longer that the coastal population, settlements and activities be very sensitive to such events: they were so in the eighteenth century, and they certainly still are, as the vulnerability can only be increased by the present increase in density of the said coastal population and activities.

When dealing with the chances of re-occurrence, continued overestimation of the height of the tsunami waves at shoreline could prove detrimental to a proper assessment of the risk, and of the need for warning, mitigation and remediation plans: the published results show that the numerical models are unable to generate waves in the 15 to $25 \mathrm{~m}$ range of height (Baptista et al., 1998b, 2003; Gutscher et al., 2006), at least when investigating plausible seismic sources: this would make the 1755 tsunami, as defined in the classical interpretation of the records, an exceptional event, out of the range of the normal possibilities of Physics: it may have appeared acceptable in the eighteenth century, when the quarrel between the "Catastrophists" and the followers of the "Actual Causes" had not yet taken place, let alone been resolved.

Somehow, it also appeared to justify the heavy impact of the event on the ideas of the time: the Priests advised the transgressors to repent, while the Philosophers pointed out to the fact that Lisbon never was more sinful than any other European capital. The Age of Enlightenment almost lost its confidence in the grace and benevolence of a Great Ordonnancer.

We now have to accept that the tsunami which caused so much damage on the south coasts of Portugal, on the gulf of Cadiz, and as well in Morocco, even if we lack the data to assess the extent of them, only reached a water height at shoreline of $2.5 \mathrm{~m}$ above tide level in Cadiz (Godin, 1755) and most likely in Tanger, decreasing to 2 and $1.5 \mathrm{~m}$ further south on the coasts of Morocco. The probability of such an event is singularly increased by its return within the range of the laws of Physics.

It may prove important to show that the alleged discrepancy between the primary record of the event and the mathematical modelling can be reconciled, to reach a plausible evaluation of the earthquake and tsunami, and show that the warning, mitigation and remediations plans which will be implemented remain in proportion to what is to be expected, as shown by the strongest event known in the area since the records are sufficiently detailed.

Edited by: S. Tinti

Reviewed by: two anonymous referees

\section{References}

Abe, K.: Size of Great Earthquakes of 1837-1974 Inferred From Tsunami Data, J. Geophys. Res., 84(B4) 1561-1568, 1979.

Anonyme: Extrait d'une lettre de Salé du 16 9bre ecrite par un religieux de l'ordre de St françois, envoyée à son Général à Madrid, et traduite de l'Espagnol, Archives Nationales de France, Affaires Etrangères BI/272-AI/831, 1755.

Baptista, M. A., Heitor, S., Miranda, J. M., Miranda, P., and Mendes Victor, L.: The 1755 Lisbon tsunami; evaluation of the tsunami parameters, J. Geodyn., 25(2), 143-157, 1998a.

Baptista, M. A., Miranda, P. M. A., Miranda, J. M., and Mendes Victor, L.: Constraints on the source of the 1755 Lisbon tsunami inferred from numerical modelling of historical data on the source of the 1755 Lisbon tsunami, J. Geodyn., 25(2), 159-174, 1998b.

Baptista, M. A., Miranda, J. M., Chierici, F., and Zitellini, N.: New study of the 1755 earthquake source based on multi-channel seismic survey data and tsunami modeling, Nat. Hazards Earth Syst. Sci., 3, 333-340, 2003, http://www.nat-hazards-earth-syst-sci.net/3/333/2003/.

Baptista, M. A. and Miranda, J. M.: Revision of the Portuguese catalog of tsunamis, Nat. Hazards Earth Syst. Sci., 9, 25-42, 2009, http://www.nat-hazards-earth-syst-sci.net/9/25/2009/.

Bewick, B.: LETTER XIV. An account of the Earthquake at Cadiz, 1 November, 1755, in a Letter from Benjamin Bewick, Merchant there (...), Philos. Trans. XLIX (I), 424-427, 1756.

Blanc, P.-L.: The tsunami in Cadiz on 1 November 1755: a critical analysis of reports by Antonio de Ulloa and by Louis Godin, C. R. Geosci., 340(4), 251-261, 2008.

Blanco Moyano, B.: 250 Aniversario del Tsunami que Barrió Andalucía Occidental, Marina Civil, 79, 59-64, October-December 2005.

Chatelain, M.: Le Maroc des Romains, Etude sur les centres antiques de la Mauritanie occidentale, edited by: de Boccard, F., Paris, 317 pp., 1968.

Davison, Ch.: Great earthquakes. London: Allen and Unwin (T. Murby), London, xii + 286 pp., ill. and maps, 1936.

Do Couto, L.-M.: Memorias para historia da praça de Mazagaõ, Luís Maria do Couto de Albuquerque da Cunha: Fide Goulven, 1917, date unknown.

F. F. B. J. (Anonymous): Extract of a Letter from a Gentleman at Gibraltar to his Friend in Dublin, dated 29 November, containing a more particular Account of the Effects of the Earthquakes in Africa, than hath hitherto been published, Felix Farley's Bristol Journal, 17 to 24 January, 1756.

Fowke, Th.: Account of the Earthquake that happened in Barbary on the 1st, 18th and 19th November 1755. Gibraltar Archives, Public Record Office, m.s. C.O. 91/12, (In Morsy, 1976), 1756a.

Fowke, Th.: LIX. LETTER XVI. An account of the Earthquake, that happened in Barbary, inclosed in a Letter from General Fowke, Governor of Gibraltar, to the Right Honourable Henry Fox, Esq., one of his Majesty's principal Secretaries of State. 
Communicated by the Right Honourable Philip Lord Viscount Royston, F. R. S. Philos. Trans. XLIX (I), 428-432, 1756 b.

Godin, L.: Sur le Tremblement de Terre qui s'est fait sentir à Cadix le 1er novembre 1755 (lu par Bouguer), P.-V. Acad. Roy. Sci. Paris, 74, 772-781, 3 and 6 décembre 1755.

Goulven, J.: La Place de Mazagan sous la domination Portugaise (1502-1769), Paris, 164-166, 1917.

Gutscher, M.-A., Baptista, M. A., and Miranda, J. M.: The Gibraltar Arc seismogenic zone (part 2): Constraints on a shallow east dipping fault plane source for the 1755 Lisbon earthquake provided by tsunami modelling and seismic intensity, Tectonophysics, 426, 153-166, 2006.

J. H. M. T. (Anonymous): De Portugal. Journal Historique sur les Matières du Tems, Tome LXXIX, 39-41, January 1756a.

J. H. M. T. (Anonymous): Afrique. Journal Historique sur les Matières du Tems, Tome LXXIX, 135-138, February 1756b.

Levret, A.: The effects of the November 1, 1755 "Lisbon" earthquake in Morocco, Tectonophysics, 193, 83-94, 1991.

Mairan, J.-J. (Ed.): Extrait de plusieurs lettres que le Général de St François a reçues des Missionnaires de son Ordre qui se trouvent dans le Royaume de Maroc. De Miquenez le 8 novembre 1755 and Extrait d'une Lettre de Tétuan du 24 Novembre 1755, P.V. Acad. Roy. Sci. Paris, 75, 4-5, 7 January 1756.

Martínez Solares, J. M. and López Arroyo, A.: The great historical 1755 earthquake, Effects and damage in Spain, J. Seism., 8(2), 275-294, 2004

Mendes-Victor, L., Ribeiro, A., Matias, L., Baptista, M.A ., Miranda, J. M., Miranda, P., Zitellini, N., Garcia, E., Corela, C., Terrinha, P., Rovere, M., and Teixeira, F. : Progresses in the Assessment of Tsunami Genesis and Impacts around the Portuguese Coasts, 217-230 in Tsunami, Case Studies and Recent Developments, edited by: Satake, K., Adv. Nat. and Technol. Hazards Res., Vol. 23, VIII, 356 pp., 2005.

Moratti, G., Piccardi, L., Vanucci, G., Bellardinelli, M. E., Dahmani, M., Bendkik, A., and Chenakeb, M.: The 1755 "Meknes" earthquake (Morocco): field data and geodynamic implications, J. Geodyn., 36, 305-322, 2003.

Morsy, M.: Le tremblement de terre de 1755 d'après les témoignages d'époque, Hesperis Tamuda 1975, 16, 89-98, 1976.
Navarro y Almijo, J., (Ed): Extensa y completa relacion de todo que acaecide de estragos, y muertes en el Reyno de Berberia, en el Passado Terremoto Con Licencia. En SevillaImprenta de D. Joseph Navarro y Almijo, en cale Genova. 8 pp., 1755.

Partyet, Mr.: Lettre consulaire de Madrid du 15 décembre 1755, Archives Nationales de France/Marine B7/396, 1755a.

Partyet, Mr.: Lettre consulaire de Madrid du 22 décembre 1755, Archives Nationales de France/Marine B7/396, avec annexe, $1755 b$.

Partyet, Mr.: Extrait de plusieurs lettres que le Général de St. François a reçues des Missionnaires de son ordre qui se trouvent Dans le Royaume de Maroc. Traduction annexée à la lettre consulaire de Madrid du 22 décembre 1755, Archives Nationales de France/Marine B7/396, 1755c.

Pereira de Sousa, F.-L.: O Terremoto do 1 de Novembro de 1755 em Portugal e un Estudo Demographico; Distritos de Faro, Beja e Evora, Lisboa, Vol. I, Cap ${ }^{l o}$, IV, O maremoto e efeitos geologicos, 84-90, 1919.

Reid, H. F.: The Lisbon Earthquake of November 1, 1755, B. Seismol. Soc. Am., 4(2), 54-80, 1914.

Sanz, A. (Ed.): Copia de Carta, Escrita por el Padre Guardian del Real Convento de Mequinez, y Vice-Prefecto Apostolico de la Santas Missiones, que en la Partes de Berberia conserva la Religiosa provincia de san Diego, de RR. PP. Franciscos Descalzos, al Padre Procurador de Ellas. Con Licencia. En Madrid... Imprenta de Antonio Sanz, en la calle de la Paz, 8 pp., 1755.

Soyris, Mr.: Extrait d'une lettre de Maroc en datte du 5 novembre 1755: de Soyris a Guys, Archives Nationales de France, Marine B7/403, 1755.

de Ulloa, A.: LETTER XV. An account of the Earthquake at Cadiz, in a Letter to the Spanish Ambassador at the Hague, from Don Antonio d'Ulloa, F. R. S. Philos. Trans. XLIX (I), 427-428, 1756.

Wolsall, Mr.: LIX. LETTER II. An Account of the Earthquake at Lisbon, 1 November 1755, in two Letters from Wolsall, Surgeon, to James Parsons, M. D., F. R. S. Philos. Trans. XLIX (I), 402407, 1755. 